\title{
PHYTOCHEMICAL SCREENING AND ANTIBACTERIAL POTENCY OF JERUK KUNCI FRUIT WASTE (Citrus $x$ microcarpa Bunge) EXTRACT AGAINST Propionibacterium acnes
}

\author{
Occa Roanisca ${ }^{1 *}$, Rani, dan Robby Gus Mahardika \\ ${ }^{1}$ Program Studi Kimia, Fakultas TeknikUniversitas Bangka Belitung, Bangka, Indonesia \\ *Email: occaroanisca@gmail.com
}

Diterima: 7 April 2021. Disetujui: 12 Mei 2021. Dipublikasikan: 2 Juni 2021

\begin{abstract}
The growth of acne bacteria can be treated using antibacterial compounds, a plant that has the potential to be developed as an acne antibacterial Citrus $x$ microcarpa Bunge (jeruk kunci). Based on the literature review, the genus Citrus contains steroids, flavonoids, terpenoids, tannins, and saponins with bioactivity as antioxidants and antibacterials. This study aims to determine the secondary metabolite content and antibacterial activity of jeruk kunci fruit waste extract against Propionibacterium acnes. In this study, the extraction used the maceration method with ethanol as a solvent. The determination of the phytochemical test was carried out qualitatively. The antibacterial test was conducted by the disc diffusion method. The results of the phytochemical test contained secondary metabolites, such as flavonoids, tannins, terpenoids, and steroids. Based on the data from the antibacterial test of the Jeruk Kunci fruit waste extract, it was found that the antibacterial power of the extract against P. acnes was relatively strong. In conclusion, the extract of the Jeruk Kunci fruit waste can be developed as an antibacterial agent.
\end{abstract}

Keywords: Acne, Antibacterial, Citrus x microcarpa Bunge, phytochemical, Propionibacterium acnes.

\section{INTRODUCTION}

Acne is a skin problem caused by bacteria. One of the bacteria that causes acne is Propionibacterium acnes. The growth of acne bacteria can be inhibited by using antibacterial compounds. Antibacterial compounds are chemicals that can inhibit and kill pathogenic bacteria. It can be synthetic compounds such as erythrosin, clindamycin, sulfur, and natural compounds [1]. However, using the same synthetic antibacterial compounds for a long time will cause resistance [2]. So that, it is necessary to seek a new alternative antibacterial compound that is safe and more active by utilizing secondary metabolites from plants as antibacterial $P$. acnes.

The plant with the potential to be developed as an acne antibacterial agent is the jeruk kunci (Citrus $x$ microcarpa Bunge). Jeruk kunci is a plant that belongs to the Rutaceae family, which has been developed and then popular throughout Southeast Asia, especially the Philippines. This plant is also commonly found in Bangka Belitung, and the people of Bangka Belitung widely use the fruit to give a sour taste to food and drinks. Jeruk kunci has many benefits, including being rich in minerals and vitamin $\mathrm{C}$. Based on the literature review of the genus Citrus, sweet orange peels ( $C$. sinensis) and lemon ( $C$. limon) using several solvents with different polarities showed steroid compounds, tannins, flavonoids, alkaloids, terpenoids, and saponins [3]. The study of the bioactivity of the peel of sweet orange (C.sinensis) conducted has the potential to be antibacterial and antioxidant [4].

The review of phytochemicals and bioactivity of the genus Citrus was conducted for microcarpa Bunge from Bangka Belitung. The research will be carried out on qualitative phytochemical and antibacterial activity against Propionibacterium acnes.

\section{EXPERIMENTAL}

The research was conducted in FebruaryAugust 2020 in the integrated chemistry and microbiology laboratory, faculty of agriculture, fisheries, and biology, University of Bangka Belitung.

The materials used in this research are jeruk kunci fruit waste (C. $x$ microcarpa Bunge), dimethyl sulfoxide (DMSO), 96\% ethanol, nutrient agar (NA), nutrient broth (NB), Propionibacterium acnes bacteria, Mayer reagent, Dragendroff reagent, Wagner reagent, $\mathrm{H}_{2} \mathrm{SO}_{4}, \mathrm{FeCl}_{3}, \mathrm{Mg}$, methanol, $\mathrm{CH}_{3} \mathrm{COOH}, \mathrm{HCl}$, aluminum foil, cotton, alcohol swab, disc paper, distilled water, $\mathrm{Na}_{2} \mathrm{CO}_{3}$, Clindamycin, filter paper, and $\mathrm{NaCH}_{3} \mathrm{COO}$. The tools are blender, analytical balance, glassware (pyrex), auto clave, rotary evaporator, water bath, dropper pipette, vortexs, caliper, loop needle, micropipette, stirring rod, label paper, bunsen burner, petri dishes, 80 mesh sieve, microscope, cotton buds, laminar air flow, test tubes, glass jars.

\section{Sample Preparation}

Jeruk kunci fruit waste (C. $x$ microcarpa Bunge) as samples in this study derived from Paya Benua Village, Mendo Barat District, Bangka Regency, Bangka Belitung Islands. The samples of jeruk kunci fruit waste obtained were then sorted wet, dried under direct sunlight. After that, it is blended into a dry powder which is then macerated. 


\section{Extraction}

The 250 grams of simplicia were macerated using $2.5 \mathrm{~L}$ of ethanol for $3 \times 24$ hours. They were stirring every $1 \times 24$ hours to obtain a concentrated extract. The filtrate obtained was concentrated with a vacuum rotary evaporator [5].

\section{Phytochemical Testing}

Qualitative testing of the secondary metabolites of jeruk kunci fruit waste extract by using several reagents. Qualitative secondary metabolic testing work procedures are as follows [6]:

\section{Alkaloids Test \\ Tested with Wagner, Dragendroff, Mayer reagents by adding $1 \mathrm{~mL} \mathrm{H}_{2} \mathrm{SO}_{4} 2 \mathrm{~N}$ was shaken vigorously. The formation of sediment indicates the presence of alkaloid compounds. The positive results of Mayer's reagent were white deposits, Dragendroff was red-orange with residue, and Wagner produced brown deposits.}

\section{Saponin Test}

Saponins were detected with hot water with the addition of 2 drops of $2 \mathrm{~N} \mathrm{HCl}$. The sample is positive if it contains a lot of foam and is consistent for 10 minutes.

\section{Tannin / phenolhydroquinonetest}

A total of $1 \mathrm{~mL}$ of sample ethanol extract was added with $1 \% \mathrm{FeCl}_{3}$ as much as 2-3 drops. A positive sample contains phenol if it produces a blackish-blue color.

\section{Flavonoid Test $(\mathrm{HCl}+\mathrm{Mg})$}

Sample $1 \mathrm{~mL}$ of ethanol extract, add 2 drops of concentrated $\mathrm{HCl}$ while shaking firmly, add $\mathrm{Mg}$ powder, and shake vigorously. The presence of flavonoids is indicated by change the color of the solution to orange or red color.

\section{Terpenoid and Steroid Test}

A total of 3 drops of the sample extract in the test tube were added 3 drops of glacial acetic acid. The mixture was then added with 5 drops of concentrated $\mathrm{H}_{2} \mathrm{SO}_{4}$ through the tube wall. Samples containing terpenoids are indicated by the presence of a purple or red solution and blue or green if they have steroids.

\section{Antibacterial Testing}

Propionibacterium acnes bacteria were inoculated on nutrient agar, $6 \mathrm{~mm}$ disc paper is placed on the media surface total of $50 \mu \mathrm{L}$ was taken from each test solution with various concentrations of $20 \%, 40 \%, 60 \%, 80 \%$, and $100 \%$ $(\mathrm{w} / \mathrm{v})$ as well as positive control and negative control solutions. The positive control used clindamycin, and the negative control used distilled water. They then entered into the concentration variations that have been made. Incubated for 24 hours at $37^{\circ} \mathrm{C}$ [7]. To see the zone of inhibition formed from the test using a caliper [8]. Measurement of the clear zone formed as an inhibition against bacterial growth. The category of antibacterial inhibition according to Davis and Stout (1971), the inhibition zone diameter $<5 \mathrm{~mm}$ is classified as weak, $5-10 \mathrm{~mm}$ is moderate, and 10$20 \mathrm{~mm}$ is classified as strong, and $20 \mathrm{~mm}$ is classified as very strong.

\section{RESULTS AND DISCUSSION \\ Phytochemical testing}

Phytochemical testing serves to identify the active compounds contained in the ethanol extract of the sample. Several reagents are used to identify phytochemical compounds such as alkaloids, saponins, tannins/phenols hydroquinone, flavonoids, terpenoids, and steroids. The results of phytochemical testing are presented in (Table 1).

Table 1 shows the phytochemical test. The ethanol extract of the sample contains bioactive compounds in the form of terpenoids, phenol hydroquinone/tannins, flavonoids, and steroids. In the alkaloid test of the ethanol extract of the sample, there was no precipitate because it did not react with the reagents. It was stated that the extract did not contain alkaloids. In contrast, alkaloid compounds have the characteristic feature of having a nitrogen atom. The nitrogen atom makes the alkaloid be base.

Flavonoid identification. The results of phytochemical testing of the ethanol extract of the sample indicated flavonoids marked by a change in color to orange or red. Generally, flavonoids dissolve in ethanol because they are polar. Ethanol is used to free flavonoids from their salt form. Addition of concentrated chloride to protonate flavonoids to form flavonoid salts. After the addition of magnesium powder, the formation of orange or red color in the presence of flavonoids. It due to reduction by HCL and magnesium [9].

Saponins identification. Saponins are active substances that contain foam. Phytochemical test results show negative results because no stable foam is formed. Saponins have a steroid group as a nonpolar group and a glycosyl group as a polar group. The two groups will produce micelles when shaken with water. In the micellar structure, the polar groups face outwards while the nonpolar groups point inward, which produces foam [10]. 
Table 1. Phytochemical Test Results of jeruk kunci fruit waste extract.

\begin{tabular}{lll}
\hline Test & Indicator & Result \\
\hline $\begin{array}{l}\text { Alkaloids } \\
\text { Mayer reagent }\end{array}$ & $\begin{array}{l}\text { The precipitation is - } \\
\text { white } \\
\text { The precipitation is - } \\
\text { brown }\end{array}$ & \\
Wagner's reagent & $\begin{array}{l}\text { The precipitation is } \\
\text { orange red }\end{array}$ & \\
Dragendrof reagent & Contains foam & - \\
Saponins & Blackish blue & + \\
Phenol & Orange & + \\
Hydroquinone / Tannin & Brownish red & + \\
Flavonoids & Green & + \\
Terpenoids & & \\
Steroids & & \\
\hline
\end{tabular}

Phenol hydroquinone/tannin identification testing. The tannin content of the sample ethanol extract showed positive results with a marked blackish-blue color change because $\mathrm{FeCl}_{3}$ reacts with the aromatic-OH group [11].

Terpenoid and steroid identification. The lieberman-Burchard reagent is used to identify steroids and terpenoids. The reagents used were $\mathrm{H}_{2} \mathrm{SO}_{4}$ and $\mathrm{CH}_{3} \mathrm{COOH}$ [10]. The phytochemical test of the ethanol extract of the sample showed a positive result of the formation of a brownish-red color for the terpenoid test and blue for the steroid test. Sulfuric acid with glacial acetic acid solvent functions to protonate the hydroxy groups on steroids or terpenoids, forming a greenish-blue color [12].

It is similar to what was expressed in previous studies. The FT-IR spectrum shows the presence of $\mathrm{OH}$ groups overlapping with the aromatic signal at $3159-3050 \mathrm{~cm}-1$ which is supported by the $\mathrm{C}=\mathrm{C}$ signal. The research states that the extract of the Jeruk Kunci may contain phenolic compounds such as phenolic acids and flavonoids [13]. Other studies claim that the fruit peel extract $\mathrm{C}$ microcarpa phenolic compounds and flavonoids, which phenolic levels higher than the Merdeka lime and a higher level of flavonoids than C. hystrix [14].

Based on the research of Lou and Ho (2016), HPLC analysis of C. $x$ microcarpa extract contains many major glucosylated flavonoids. The compound 3', 5' -di-C- $\beta$-glucopyranosylphloretin and Apigenin-6,8-di-C glucoside (vicenin-2) is a compound that is extracted major falvonoid with respective levels of $2335 \pm 22$ and $637 \pm 21 \mathrm{mg} /$ 100 gr dry [15]. The structure of the two compounds is presented in Figure 1. Based on phytochemical analysis and literature review, it shows that the dominant active compounds in Jeruk Kunci are phenolic and flavonoids.

\section{Determination of Antibacterial Activity}

An antibacterial test was used to determine the inhibitory strength of the ethanol extract of the sample against the growth of $P$. acnes bacteria using the disc diffusion method. Disc diffusion is used to determine whether there is an effect of ethanol extract samples on $P$. acnes. The medium used for bacterial growth is nutrient agar. The use of agar nutrients is a common medium for bacterial growth. Aquadest as a negative control and clidamycin as a positive control. Antibacterial activity the extract by looking at the formation of a clear zone around the disc paper. The clear zone that is formed is called the zone of inhibition. Measurement of the developed zone of inhibition uses a caliper. Based on the results of the research, the inhibition test carried out on the ethanol extract of the sample obtained the results in (Table 2):<smiles>O=C(CCc1ccc(O)cc1)c1c(O)c(C(O)C(O)CO)c(O)c(C2OCC(O)C(O)C(O)C(O)C2O)c1O</smiles>

$3^{`}, 5^{`}$-di-C- $\beta$-glucopyranosylphloretin

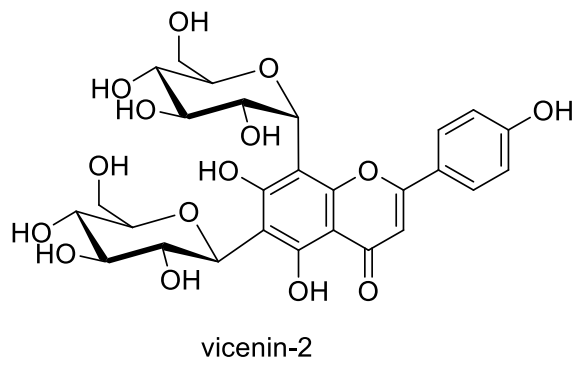

Figure 1. Structure of the Jeruk Kunci flavonoid compound [15] 


\section{Description: + Positive control - Negative control}

Table 2 shows that the mean inhibition zone formed from variations in the concentration of ethanol extract samples at concentrations of $20 \%$, $40 \%, 60 \%, 80 \%$, and $100 \%$ has antibacterial activity against $P$. acne bacteria in the strong category (Figure 2).

Figure 2 shows that the higher the ethanol extract concentration of the sample, the higher the average inhibition zone formed. Positive control has potent bacterial inhibition; negative control has no bacterial inhibition. It is because distilled water does not have antibacterial properties against $P$. acnes. Then the variation in pure concentration of the ethanol extract of the sample is not influenced by the solvent. The ethanol extract of the sample was able to inhibit the growth of $P$. acne because it had antibacterial properties. The inhibitory power of the sample ethanol extract against $P$. acnes of low concentrations has been shown great inhibition. The extract can be used as an invention that can be developed in the future to be used as an antibacterial agent. Inhibitory power as antibacterial of the ethanol extract samples is the possibility of a synergistic collaboration between the compounds contained in the sample ethanol extracts such as flavonoids, phenols, terpenoids, steroids, and tannins.

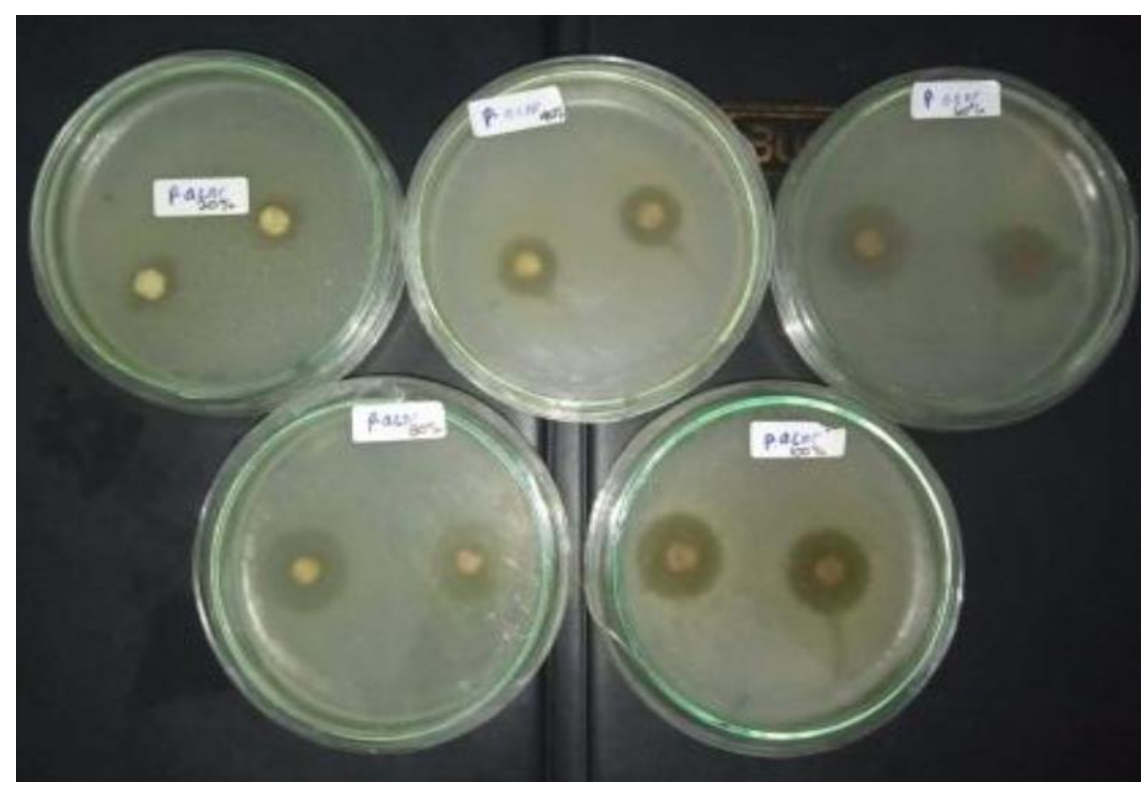

Figure 2. The inhibition zone of the antibacterial test

Table 2. Test data for antibacterial extracts against Propionibact

\begin{tabular}{|c|c|c|c|c|}
\hline \multirow{2}{*}{ Extract Concentration } & \multicolumn{2}{|c|}{ Inhibition Zone Diamete } & \multirow{2}{*}{ Average $(\mathrm{mm})$} & \multirow{2}{*}{ Category } \\
\hline & & 2 & & \\
\hline $20 \%$ & 8.88 & 11.75 & 10,315 & Strong \\
\hline $40 \%$ & 12.13 & 11.31 & 11,72 & Strong \\
\hline $60 \%$ & 15.11 & 15.37 & 15,24 & Strong \\
\hline $80 \%$ & 15.35 & 16.37 & 15,86 & Strong \\
\hline $100 \%$ & 16.51 & 16.94 & 16,73 & Strong \\
\hline Clindamycin (+) & 30.35 & 30.35 & 30.35 & Very strong \\
\hline Aquades $0(-)$ & 0 & 0 & 0 & - \\
\hline
\end{tabular}

The mechanism of flavonoid inhibition as an antibacterial is by inhibiting energy metabolism. It inhibits the use of oxygen through the movement of bacteria that play a role in microbial activity and extracellular protein and prevents the formation of cytoplasmic energy. Inhibits nucleic acid synthesis where the A and B rings of flavonoids play an essential role in the hydrogen bonding process by accumulating nucleic acid bases to be inhibited in the formation of DNA and RNA. Limiting the function of the cell membrane through the formation of complex compounds from extracellular proteins on flavonoids, causing the cell membrane to break out of the intracellular compounds [16]. The phenolic mechanism in inhibiting bacteria by increasing the cytoplasmic 
membrane permeability causes cytoplasmic coagulation and leakage of intracellular components resulting in lysis or death [17]. The mechanism of action of terpenoid as antibacterials is as follows: steroid compounds are able to interact with cell phospholipid membranes, resulting in decreased membrane integrity and changes in cell morphology so that cells become brittle and undergo lysis [18]. Inhibition of terpenoid compounds is by reacting with porin (transmembrane protein) on the outer membrane of the bacterial cell wall. Then the formation of strong polymer bonds that destroy porin [19]. The tannin/phenol hydroquinone as an antibacterial is by inhibiting the transcriptase enzyme so that DNA topoisomerase is not formed. Other tannins' mechanism as antibacterials is by activating cell adhesin, activating enzymes, and disrupting protein transport. Disruption in bacterial cell protein synthesis due to the presence of tannin compounds will have fatal consequences, which lead to bacterial cell death [20].

\section{CONCLUSION}

Based on the our finding it can be concluded that jeruk kunci fruit waste contains secondary metabolites terpenoids, phenolhydroquinone/ tannins, flavonoids, and steroids. Jeruk kunci fruit waste has antibacterial activity against the Propionibacterium acnes bacteria with strong category.

\section{ACKNOWLEDGMENTS}

Researchers are grateful for teamwork. Thank for the Laboratory Analysis of the use of tools and materials and analytical assistance.

\section{REFERENCES}

[1] Roanisca, O., \& Mahardika, R.G. (2020). Citrus x microcarpa bunge Fruit Extract as Antibacterial Against Staphylococcus aureus. IOP Conf. Series: Earth and Environmental Science ICoGEE 2020.

[2] Sholih, M.G., Ahmad, M. dan Siti, S. (2015). Rasionalitas Penggunaan Antibiotik di Salah Satu Rumah Sakit Umum di Bandung Tahun 2010. Jurnal Farmasi Klinik Indonesia. 4(1) : 63-70.

[3] Kumar, A., Narayani, M., Subanthini, A. \& Jayakumar, A. (2011). Antimicrobial Activity and Phytochemical Analysis of Citrus Fruit peels-Utilization of Fruit Waste. International Journal of Engineering Science and Technology. 3(6): 5414-542.

[4] Wijiastuti, L. (2011). Aktivitas Antibakteri Ekstrak Etanol Kulit Buah Jeruk Manis (Citrussinensis (L.) Osbeck) terhadap Staphylococcus aureus dan Escherichia coli Multiresisten serta Brine Shrimp Lethality
Test. Skripsi. Universitas Muhammadiyah Surakarta, Surakarta.

[5] Dungir, Stevi, G., Dewa, G., Katja, Vanda S. (2012). Aktivitas Antioksidan Ekstrak Fenolik Dari Kulit Manggis (Garcinia mangostana L). Jurnal Mipa Unsrat. 1(1): $11-15$

[6] Roanisca, O. (2018). Skrining Fitokimia dan Potensi Antibakteri Ekstrak Etanol Pucuk Iding-iding (Stenochlaena palustris) Terhadap Bakteri Bacillus subtilis, Staphylococcus aureus, dan Escherichia coli. Jurnal Kimia Mulawarman. 15 (2):99105.

[7] Jagessar, R.A., Mars, G., Gomes. (2008). Selective Antimicrobial Properties of Phyllanthus acidus Leaf Extract Against Candida albicans, Escherichia coli and Stapyloccocus aureus Stokes Disc Diffussion, Well Difuscion, Streak Plate and a Dilution Method. Nature and Science. (6): 24-38.

[8] Maida, S., Lestari, K.A.P. (2019). Aktivitas Antibakteri Amoksisilin Terhadap Bakteri Gram Positif Dan Bakteri Gram Negatif. Jurnal Pijar MIPA. 14 (3): 189-191.

[9] Rahayu, S, Nunung, K, Vina, A. (2015). Ekstraksi Dan Identifikasi Senyawa Flavonoid Dari Limbah Kulit Bawang Merah Sebagai Antioksidan Alami. Al kimiya. 2(1):1-8.

[10] Sangi, M, R, M, S, H. .(2008). Analisis Fitokimia Tumbuhan Obat di Kabupaten Minahasa Utara. Chem, Prog. 1(1) :47-53.

[11] Haryati, Nur. A, Chairul. S, Erwin. (2015). Uji Toksisitas dan Aktivitas Antibakteri Ekstrak Daun Merah (Syzygium mytifolium Walp) Terhadap Bakteri Stapyloccocus aureus dan Eschericia coli. Jurnal Kimia Mulawarman. 13(1):35-39.

[12] Marlinda, M., S, M, W, A. (2012). Analisis Senyawa Metabolit Sekunder dan Uji Toksisitas Ekstrak Etanol Biji Buah Alpukat (Persea americana Mill.). Jurnal Kimia Unsrat. 1(1):24-28.

[13] Roanisca, O., \& Mahardika, R. G. (2020). Citrus $\mathrm{x}$ microcarpa bunge fruit extract as antibacterial against Staphylococcus aureus. IOP Conference Series: Earth and Environmental Science, 599(1).

[14] Z, N. I., Norhayati, Y., Syara, K., \& W, N. H. A. (2019). Qualitative Phytochemical Screening and Antioxidant Activities from Three Different Citrus Leaves ( Rutaceae). Preprints, 1(1), 1-6.

[15] Lou, S. N., \& Ho, C. T. (2017). Phenolic compounds and biological activities of small-size citrus: Kumquat and calamondin. Journal of Food and Drug Analysis, 25(1), 162-175. 
[16] Rijayanti, R.K. (2014). Uji Aktivitas Antibakteri Ekstrak Etanol Daun Mangga Bacang (Mangifera foetida L) Terhadap Stapyloccocus Aureus Secara In 29 Vitro. Naskah Publikasi. Program Studi Pendidikan Dokter, Fakultas Kedokteran, Universitas Tanjungpura.

[17] Supriyanto, M., I. (2005). Aktivitas Pemberian Ekstrak Temulawak (Curumae xanthoriza) dan Kunyit (Curcumae domestica) Terhadap Eschericia coli dan Staphylococcus aureus. Jurnal Biologi. 11:15-23.

[18] Sudarmi, K., Darmayasa, I.B.G., \& Muksin, I.K. (2017). Uji Fitokimia dan Daya Hambat Ekstrak Daun Juwet (Syzygium cumini) Terhadap Pertumbuhan Escherichia coli dan Staphylococcus aureus ATCC. Jurnal Simbiosis. 2: 47-51.

[19] Muchtaromaha, B., Safitrib, E.S., Fitriasaric, P.D., and Istiwandhanid, J. (2020). Antibacterial activities of curcuma mangga Val. extract in some solvents to Staphylococcus aureus and Escherichia coli. AIP Conference Proceedings, Chapter 2231 : 030005-1 -03005-6.

[20] Othman, L., Sleiman, A., and Abdel-Massih, R.M. (2019). Antimicrobial activity of polyphenols and alkaloids in middle eastern plants. Frontiers Microbial. 10: 1-28. 